\title{
ОСОБЛИВОСТІ ВИКЛАДАННЯ МЕДИЧНОГО ПРАВА ДЛЯ СТУДЕНТІВ-МЕДИКІВ
}

\author{
I. O. Rohalskyi, N. M. Kalyniuk \\ I. Horbachevsky Ternopil State Medical University \\ PECULIARITIES OF MEDICAL LAW TEACHING FOR MEDICAL \\ STUDENTS
}

\begin{abstract}
Мета роботи - дослідження особливостей викладання дисципліни “Медичне право України” для студентів-медиків.
Основна частина. У статті досліджено проблемні моменти викладання дисципліни “Медичне право України” для студентів неюридичних спеціальностей, зокрема для студентів-медиків. Проаналізовано окремі аспекти навчальної програми з медичного права. Обгрунтовано необхідність вдосконалення методів та технологій викладання медичного права для студентів-медиків.

Визначено, що вітчизняна нормативно-правова база має положення, що регулюють права громадян у сфері охорони здоров’я. Однак євроінтеграційний вектор розвитку нашої країни, збільшення обсягів міждержавних обмінів, розвиток ринкових відносин, потребує вивчення та ревізії вітчизняного права, врахування кращого світового досвіду участі професійних і громадських організацій щодо захисту прав медичних працівників та пацієнтів, зобов’язує науковців і законодавчі органи удосконалювати нормативну базу в галузі охорони здоров'я. А впровадження та вивчення ії у вищих навчальних закладах забезпечить імплементацію медичного права в систему права України.

Висновки. Доведено, що навчальна дисципліна “Медичне право України” включає в себе норми інших галузей права, що регулюють суспільні відносини, учасниками яких є медичні працівники та пацієнти. Це надає змогу студентам-медикам вивчити та знати ази конституційного, цивільного, адміністративного, кримінального законодавства.
\end{abstract}

Ключові слова: медичне право; педагогіка; викладання; навчальна дисципліна.

The aim of the work - to study the peculiarities of Medical Law of Ukraine teaching for medical students.

The main body. The article deals with the problem points of Medical Law of Ukraine teaching for students of non-legal specialties, in particular for medical students. Some aspects of the medical law curriculum have been analyzed. The necessity of improving methods and technologies of teaching medical law for medical students is substantiated.

It is determined that the domestic legal and regulatory framework has provisions regulating the rights of citizens in the field of health care. However, the European integration vector of our country's development, the increase of interstate exchanges, the development of market relations, requires the study and revision of domestic law, taking into account the best world experience of the participation of professional and non-governmental organizations in the protection of the rights of medical workers and patients, obliges scholars and legislators to improve the regulatory framework in the field of health care. Introduction and study of it in higher educational institutions will ensure the implementation of medical law in the system of law of Ukraine.

Conclusions. It has been proved that the academic discipline Medical Law of Ukraine includes the norms of other branches of law regulating social relations, participants of which are medical workers and patients. This allows medical students to study and know the basics of constitutional, civil, administrative, criminal law.

Key words: medical law; education; teaching; training course.

Вступ. Проблематика забезпечення прав громадян у всіх галузях суспільних відносин у наш час займає передове місце серед усіх актуальних проблем сьогодення. Це зумовлене хоч і повільним, проте невпинним поступом України до європейської спільноти, що вимагає дотримання прав і свобод людини повною мірою.

\footnotetext{
() I. О. Рогальський, Н. М. Калинюк
}

Важливим напрямом гуманітарної політики держави $є$ здійснення реформування сфери охорони здоров’я. Правова держава постійно регулює та вдосконалює питання нормативно-правового забезпечення даної галузі [1]. Зважаючи на універсальний характер права, постає питання про необхідність адекватного юридичного забезпечення медичної діяльності. 
Підвищення вимог до працівників сфери охорони здоров'я, розбудови системи вищої освіти, інтеграції іï̈ у європейський простір, зумовило необхідність напрацювання нових підходів до виховання новітнього покоління фахівців, спроможних професійно відповідати на виклики часу, дотримуючись принципів законності, захисту національних інтересів та вимог громадянського суспільства.

Проблематику викладання дисципліни "Медичне право України”як на додипломному, так і післядипломному рівнях неодноразово розглядали такі вчені, як С. Булеца, 3. Гладун, А. Заволович, Р. Майданик, І. Сенюта, В. Синиця та ін. Водночас аналіз їхніх робіт дає підстави для висновку про те, що переважна більшість із них досліджує лише окремі аспекти методики викладання означеної дисципліни. Доцільність дослідження цієї проблематики визначила I. Сенюта, наголошуючи на проблемах перманентного реформування охорони здоров'я, що відбувається в Україні [2].

Тривалий час у суспільстві була відсутня реальна правова регламентація сфери медичного обслуговування. Законодавство про охорону здоров'я мало декларативний характер, а правила надання медичної допомоги містилися у відомчих актах, що не підлягали публікації. Це зумовило неможливість врегулювання медичної сфери діяльності. На сьогодні настала потреба у вирішенні і приведенні у відповідність $з$ міжнародно-правовими стандартами механізму реалізації норм медичного права, в забезпеченні прав та свобод громадян у сфері охорони здоров'я. При цьому повинна мати місце чітка взаємодія як медичних працівників, так і юристів, а також споживачів медичних послуг.

Мета роботи - дослідження особливостей викладання дисципліни “Медичне право України” для студентів-медиків.

Основна частина. У Листі Міністерства юстиції України від 20.06.2011 р. визначено, що переважна більшість медичних працівників та навіть керівників закладів охорони здоров'я має поверхневе уявлення про юридичну відповідальність, що встановлена чинним законодавством за правопорушення у сфері охорони здоров'я [3]. Разом з тим, з одного боку, знання про підстави, види і наслідки юридичної відповідальності дисциплінують медичних працівників, а з іншого - зменшують ймовірність безпідставного притягнення їх до відповідальності. 3 цих причин вивчення дисципліни “Медичне право України” є нагальною потребою та необхідністю.
Належна підготовка фахівців-медиків повинна забезпечуватися повною обізнаністю їх у своїх правах та обов'язках й знанням елементарних норм законодавства. Аналіз чинного законодавства у галузі охорони здоров'я повинен передувати виробленню нових освітніх та навчальних програм з акцентом на тактику захисту медичних працівників і підвищення доступності населення до сучасних форм правової допомоги. Напрацьована науково-методична база потребує системного вдосконалення та додаткового опрацювання, враховуючи специфіку викладання дисципліни “Медичне право України” у медичних вищих навчальних закладах.

Викладання навчальної дисципліни "Медичне право України” для студентів-медиків підвищує рівень їх професійної підготовки. Адже вивчення проблем забезпечення реалізації права громадян на охорону здоров'я, відповідно до правових норм міжнародного та вітчизняного законодавства, правовий супровід медичної діяльності та запобігання правопорушенням у цій сфері стане значним досягненням у вирішенні для суспільства різнобічних проблемних питань і конфліктних ситуацій.

Надзвичайно важливим розділом у програмі “Медичне право України” є розділ, присвячений відповідальності лікаря. I якщо для юриста ці питання проявляються в аспекті “порушення - покарання”, то для студентів-медиків доцільно було б окремо наголосити ще й на способах попередження певних видів правопорушень, пов'язаних безпосередньо зі сферою охорони здоров'я.

При викладанні навчальної дисципліни “Медичне право України” викладач повинен враховувати психологічні особливості кожного зі студентівмедиків, відповідно визначаючи систему розроблених індивідуальних навчально-дослідницьких завдань, завдань для самостійної роботи та ін.

Особливо важливо враховувати наявність у кожній академічній групі окремих студентів 3 метою більш посиленого їх навантаження шляхом залучення до участі в предметних студентських олімпіадах, науково-дослідницькій роботі (у наукових конференціях, підготовці наукових доповідей, статей, у подальшому - дипломних і магістерських робіт тощо).

Серед можливих варіантів викладач може обрати певну модель щодо засвоєння навчальної дисципліни “Медичне право України” з урахуванням іï специфіки, урізноманітнити індивідуальні навчально-дослідницькі завдання, проекти, надати ситуативні задачі, своєрідні завдання для самостійної роботи тощо. 
У ході викладання дисципліни “Медичне право України” слід звернути увагу на правовий аспект якості надання медичної допомоги. На жаль, поінформованість лікарів щодо чинної нормативної бази системи управління якістю медичної допомоги суттєво бажає бути кращою. Адже саме через дефекти у якості лікування виникає доволі велика кількість обгрунтованих конфліктів між лікарем та пацієнтом. 3 цих причин при викладанні дисципліни “Медичне право України»” саме у студентів-медиків питанню якості надання медичної допомоги, ії стандартизації слід приділити більшу увагу.

Окрім вказаних напрямів у процесі викладання навчальної дисципліни “Медичне право України” для студентів-медиків важливим $є$ викладання правових аспектів підприємницької діяльності у сфері медичних послуг. Означене сформувало б підгрунтя правової грамотності та сприяло б їх правовому вихованню і розумінню необхідності дотримання вимог законодавства під час професійної діяльності у всіх їі сферах.

Важливим аспектом у викладанні дисципліни “Медичне право України” є кадрове забезпечення. Оптимально, якщо викладачем є особа, що має вищу юридичну освіту, науковий ступінь та/або вчене звання. В іншому випадку викладачем може бути особа, що має вищу медичну освіту, науковий ступінь та/або вчене звання і другу вищу юридичну освіту. Лише при такому кадровому забезпеченні буде можливим належне та якісне донесення нормативно-правової інформації до студентів-медиків. Це зумовить реалізацію основної мети викладання ознайомлення студентів з основними поняттями медичного права та його зв'язком з іншими дисциплінами, а також з іншими галузями та інститутами права; виховання у студентів-медиків правової свідомості, що дозволило б їм у майбутній діяльності уникнути багатьох непорозумінь, пов'язаних із порушенням прав інших громадян; навчання студентів-медиків основ правової грамотності, що дозволить їм у подальшому ефективно працювати в системі ринкових відносин у медичній діяльності, зокрема і після запровадження обов'язкового державного медичного страхування.

Спираючись на досвід викладання дисципліни “Медичне право України”, слід виокремити такі основні проблеми, як низьке кадрове забезпечення та дисбаланс у співвідношенні лекційних і семінарських годин аудиторного навантаження. Так, наприклад, перед лектором, що має обмежену кількість годин на викладання значного масиву правових знань, поряд із завданням з підготовки, проведення та належної організації занять із медичного права, щоразу постає питання, яким чином забезпечити здійснення студентами-медиками належного правового аналізу конкретних ситуацій, осмислення ними правових норм і застосування їх в окремих ситуаціях. Як відомо, сфера охорони здоров'я поєднує в собі різнорідні суспільні відносини - медичні, фінансові, управлінські, організаційні, регулювання яких здійснюється за допомогою різних правових галузей. Саме ця обставина і незначна кількість годин, що виділяється на вивчення медичного права, зумовлюють непрості умови викладання цієї дисципліни. Разом з тим, такі складні обставини стимулюють постійне вдосконалення методів та технологій викладання медичного права шляхом пошуку адекватних принципів і систем контролю за якістю і ефективністю правового навчання.

Висновки. Вітчизняна нормативно-правова база має положення, що регулюють права громадян у сфері охорони здоров'я. Однак євроінтеграційний вектор розвитку нашої країни, збільшення обсягів міждержавних обмінів, розвиток ринкових відносин, потребує вивчення та ревізії вітчизняного права, врахування кращого світового досвіду участі професійних і громадських організацій щодо захисту прав медичних працівників та пацієнтів, зобов'язує науковців і законодавчі органи удосконалювати нормативну базу в галузі охорони здоров'я. А впровадження та вивчення її у вищих навчальних закладах забезпечить імплементацію медичного права в систему права України.

Навчальна дисципліна “Медичне право України” включає в себе норми інших галузей права, що регулюють суспільні відносини, учасниками яких $є$ медичні працівники та пацієнти. Це надає змогу студентам-медикам вивчити та знати ази конституційного, цивільного, адміністративного, кримінального законодавства.

\section{Список літератури}

1. Сізінцова Ю. Ю. Викладання дисципліни “Медичне право” для студентів та курсантів вищих навчальних закладів / Ю. Ю. Сізінцова // Матеріали VI Всеукр.
(V Міжнар.) наук.-практ. конф. 3 медичного права, 2628 квітня 2012 р. - Львів : Вид-во ЛОФБ “Медицина і право”, 2012. - С. 313-318. 
2. Сенюта I. Я. Медичне право як навчальна дисципліна: “панно” багатовекторного викладання (досвід України) / І. Я. Сенюта // Медичне право України. 2015. - № 1. - С. 89-94.

\section{References}

1. Sizintsova, Yu.Yu. (2012). Vykladannia dystsypliny "Medychne pravo" dlia studentiv ta kursantiv vyshchykh navchalnykh zakladiv [Teaching of the discipline "Medical Law" for students and cadets of higher educational institutions]. Materialy VI Vseukrainskoi (V Mizhnarodnoi) naukovo-praktychnoi konferentsii z medychnoho prava (26-28 kvitnia 2012 r). Lviv: LOFB "Medytsyna i pravo" - Materials of the VI All-Ukrainian (V International) Scientific-Practical Conference on Medical Law (April 2628, 2012), 313-318 [in Ukrainian].
3. Відповідальність медичних працівників : Лист Міністерства юстиції України від 20.06.2011 р. [Електронний ресурс]. - Режим доступу : http://zakon2.rada.gov.ua/ laws/show/n0040323-11.

2. Seniuta, I.Ya. (2015). Medychne pravo yak navchalna dystsyplina: "panno" bahatovektornoho vykladannia (dosvid Ukrainy) [Medical law as an educational discipline: "panel” of multi-vector teaching (Ukrainian experience)]. Medychne pravo Ukrainy - Medical Law of Ukraine, 1, 89-94 [in Ukrainian].

3. (2011). [Vidpovidalnist medychnykh pratsivnykiv: Lyst Ministerstva yustytsii Ukrainy vid 20.06.2011 r. [Responsibility of medical staff: Letter from the Ministry of Justice of Ukraine]. Epub. June 20. Retrieved from: http:// zakon2.rada.gov.ua/laws/show/n0040323-11.

Електронна адреса для листування: rogalskyy@tdmu.edu.ua 